\title{
Author Correction: Tissue damage from neutrophil-induced oxidative stress in COVID-19
}

Mireille Laforge, Carole Elbim, Corinne Frère (D, Miryana Hémadi (D, Charbel Massaad, Philippe Nuss, Jean-Jacques Benoliel and Chrystel Becker

Nature Reviews Immunology (2020) https://doi.org/10.1038/s41577-020-0407-1 Published online 29 July 2020

In the originally published article, a sentence in the second last paragraph incorrectly used 'thrombocytosis' instead of 'thrombosis'. This sentence has now been corrected to: 'This results in biophysical and biomechanical changes in the RBC membrane that affect both the diffusion of oxygen and carbon dioxide and the deformability capability of RBCs in the capillary vessels, thereby favouring thrombosis.'

https://doi.org/10.1038/s41577-020-00425-7 I Published online 10 August 2020

(c) Springer Nature Limited 2020

\section{Publisher Correction: NK cells in COVID-19: protectors or opponents?}

\section{Aljawharah Alrubayyi}

Nature Reviews Immunology (2020) https://doi.org/10.1038/s41577-020-0408-0 Published online 30 July 2020

In the originally published article, the accompanying preprint reference was listed incorrectly. This has now been corrected in the HTML and PDF versions of the article.

https://doi.org/10.1038/s41577-020-00419-5 I Published online 4 August 2020

(C) Springer Nature Limited 2020 